\title{
REVIEWS
}

\section{Complement in the immunopathogenesis of rheumatic disease}

\author{
Gunnar Sturfelt and Lennart Truedsson
}

\begin{abstract}
The complement system has vital protective functions as a humoral component of the innate immune system and also through interactions with the adaptive immune system; however, when inappropriately activated or regulated, complement can cause inflammation and organ damage, and such processes are involved in the pathogenesis of many inflammatory conditions, not least rheumatic diseases. Furthermore, states of complement deficiency can predispose not only to infections, but also to autoimmune disorders, including rheumatic diseases such as systemic lupus erythematosus. In this Review, the mechanisms behind the pathogenic activities of complement in rheumatic diseases are discussed. Potential approaches to therapeutic intervention that focus on regulating complement activities in these disorders are also considered.
\end{abstract}

Sturfelt, G. \& Truedsson, L. Nat. Rev. Rheumatol. 8, 458-468 (2012); published online 5 June 2012; corrected online 29 June 2012; doi:10.1038/nrrheum.2012.75

\section{Introduction}

The complement system is phylogenetically old, and represents an essential part of the innate immune system. Complement comprises more than 30 proteins, which through a complex network of interactions bestow the capacity to defend against invasion by microbes, clear waste products (e.g. immune complexes [ICs], apoptotic material) and regulate cytokine production by immune cells, thus providing an interface between the innate and the adaptive immune systems.

The importance of complement to host protection is highlighted by the susceptibility of individuals deficient in various components of this system to recurrent infectious diseases. Moreover, deficiencies in a number of complement proteins and/or aberrant activity of the complement system are increasingly recognized as contributors to the pathogenetic immune responses that underlie the development and progression of various inflammatory and autoimmune disorders, including rheumatic diseases such as systemic lupus erythematosus (SLE). This Review describes the current understanding of complement system involvement in not only the pathogenesis of rheumatological conditions, but also protection against a spectrum of inflammatory rheumatic diseases. Taken together, it is hoped that the increasing knowledge in these areas will open up new therapeutic avenues; we will briefly discuss potential future approaches to management of rheumatic diseases using therapies that regulate the complement system.

\section{Competing interests}

G. Sturfelt declares an association with Active Biotech. See the article online for full details of the relationship. L. Truedsson declares no competing interests.

\section{The complement system}

The many proteins that constitute the complement system can be divided in three different functional groups: proteins involved in complement activation; proteins involved in regulation of complement activation; and cell membrane associated proteins (receptors) that interact with fragments of complement components formed during activation. The complement activation cascade components have a role in at least one of three pathways that all result in generation of $\mathrm{C} 3$ convertases, the classical, lectin and alternative pathways, or a shared downstream terminal pathway that leads to the formation of the lipophilic C5b-9-containing membrane-attack complex (MAC) which forms a pore in the target cell and promotes osmotic cell lysis (Figure 1). Components of these activation cascades have other roles in host defense, such as enhancement of phagocytic clearance through opsonization of ICs and foreign or apoptotic cells, direction of leukocyte chemotaxis and regulation of innate and adaptive immune responses. An overview of split products and complexes formed during complement activation and their biological functions is given in Table 1 and Table 2, respectively. Complement receptors (CR) represent an interface between activated complement components and cell membranes (Figure 1) and, as such, mediate many of these processes.

Self surfaces are protected against the destructive activities of complement by the inhibitory action of several proteins at various stages of the activation cascade. For example, $\mathrm{C} 3 \mathrm{~b}$ and $\mathrm{C} 4 \mathrm{~b}-$ key components of the $\mathrm{C} 3$ convertases that initiate or amplify complement responses - are inhibited by membrane cofactor protein (MCP, also known as CD46) and complement decay-accelerating factor (DAF). CR1 might also contribute to the inhibition of complement activation on a cell surface, although 
the main function of this receptor is in degradation of C3b associated with ICs (Figure 1). ${ }^{1}$ Inhibition of complement at the stage of MAC formation is provided by protectin (CD59). In the circulation, control at the level of classical pathway activation through the $\mathrm{C} 1$ complex or lectin pathway initiation via complexes of mannosebinding lectin (MBL; also known as mannose-binding protein $\mathrm{C}$ ) and mannan-binding lectin serine protease (MASP) is accomplished by plasma protease $\mathrm{C} 1$ inhibitor (C1Inh). C4b and $\mathrm{C} 3 \mathrm{~b}$ are inhibited by circulating factor I with $\mathrm{C} 4 \mathrm{~b}$-binding protein $(\mathrm{C} 4 \mathrm{BP})$ and factors $\mathrm{H}$ and $\mathrm{H}$-like protein 1 , respectively, acting as cofactors, whilst building of the C5b-9 complex is regulated by clusterin and vitronectin.

\section{Complement: crossroads and dualism}

Several examples of links between the complement system and the adaptive immune systems exist. In humans, complement is a powerful mediator not only of inflammation in defence against invading microbes, but also of inflammation and tissue damage associated with autoimmune and IC-mediated diseases. Complement can induce tissue damage directly through MAC formation or indirectly via deposition of cell-bound split products, such as $\mathrm{C} 4 \mathrm{~b}$ and $\mathrm{C} 3 \mathrm{~b}$, which activate

\section{Key points}

- Complement activation is involved in the pathogenesis of many rheumatic diseases

- Deficiencies in components of the classical pathway of complement activation, but not other complement deficiencies, are associated with development of systemic lupus erythematosus (SLE) and SLE-like disorders

- Complement activation via the alternative pathway in tissues can cause damage associated with autoimmune disease pathology

- Increased knowledge of the functions of complement will hopefully lead to identification of new therapeutic targets in rheumatic diseases

CR-expressing leukocytes. Activation of the complement cascades also promotes inflammation by generating anaphylatoxins $\mathrm{C} 3 \mathrm{a}, \mathrm{C} 4 \mathrm{a}$ and $\mathrm{C} 5 \mathrm{a}$, which are chemotactic and have cell-activating effects via induction of cytokines and other proinflammatory molecules. Furthermore, several studies have shown that complement components stimulate signalling that regulates the phenotype and function of several immune cell subsets; ${ }^{2,3}$ for example, signalling through MCP is involved in T-cell activation. ${ }^{4}$

The complement system is sometimes described as a double-edged sword, owing to its dualistic functions in host defence and in causing injury. The requirement for balance in complement activity is clearly illustrated in SLE. In this disease, complement activation contributes

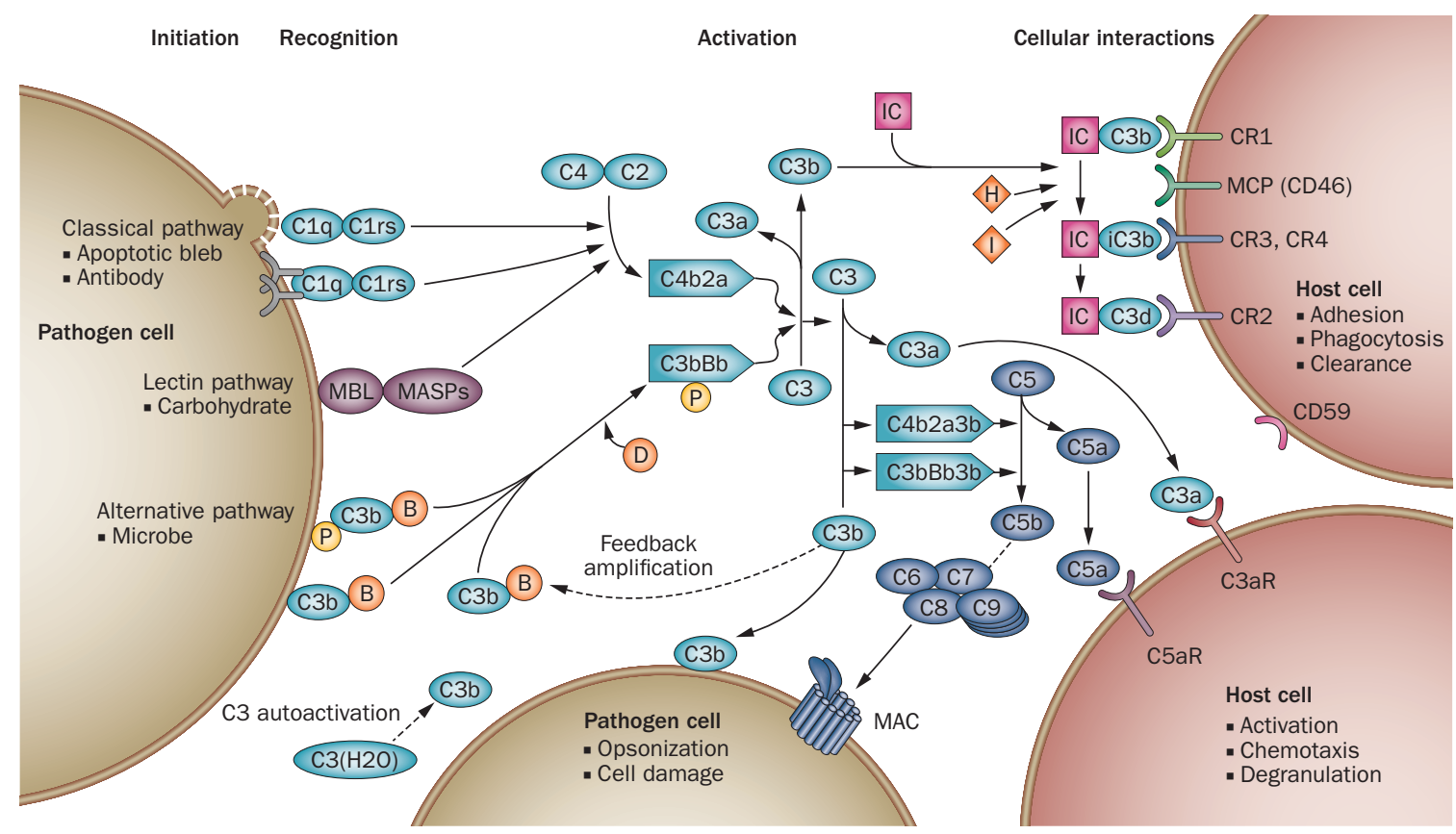

Figure 1 | Schematic representation of complement activation and important interactions between complement components and cells. The complement cascade can be activated by different stimuli through three main pathways: the classical, lectin and alternative pathways. Each of these pathways leads to cleavage and activation of $\mathrm{C} 3$, resulting in the generation of a small phlogistic C3a fragment and a larger C3b fragment that can opsonize pathogen cells and ICs and also bind to the receptor CR1 on host cells. Degradation of C3b by complement factor I in the presence of cofactors (complement factor $\mathrm{H}$, MCP and CR1) creates smaller fragments, iC3b and C3d, that interact with CR3 or CR4 and CR2, respectively, which are present mainly on phagocytic cells and B cells. Further complement activation leads to C5 cleavage and formation of the MAC. The smaller C5 cleavage fragment, C5a, is a potent chemotactic factor for phagocytes and, like C3a, is also an anaphylatoxin causing degranulation of mast cells and basophils through receptor interactions. Abbreviations:

$\mathrm{B}$, complement factor B; C3aR, C3a anaphylatoxin chemotactic receptor; C5aR, C5a anaphylatoxin chemotactic receptor; $\mathrm{CR}$, complement receptor; D, complement factor D; $\mathrm{H}$ complement factor $\mathrm{H}$; I, complement factor I; IC, immune complex; MAC, membrane attack complex; MASP, mannan-binding lectin serine protease; MBL, mannose-binding lectin; MCP, membrane cofactor protein; $\mathrm{P}$, properdin. 


\begin{tabular}{|c|c|c|}
\hline $\begin{array}{l}\text { Split } \\
\text { product }\end{array}$ & $\begin{array}{l}\text { MW } \\
(\mathrm{kDa})\end{array}$ & Description and/or function \\
\hline $\mathrm{C} 2 \mathrm{a}$ & 68 & $\begin{array}{l}\text { Larger fragment formed by cleavage of } \mathrm{C} 2 \text { during activation } \\
\text { Component of the classical pathway } \mathrm{C} 3 \text { convertase } \mathrm{C} 4 \mathrm{~b} 2 \mathrm{a}\end{array}$ \\
\hline $\mathrm{c} 2 \mathrm{~b}$ & 30 & Smaller fragment formed by cleavage of $\mathrm{C} 2$ during activation \\
\hline C3a & 8 & $\begin{array}{l}\text { Smaller fragment formed by cleavage of } \mathrm{C} 3 \text { during activation } \\
\text { Complement anaphylatoxin } \\
\text { Chemotactic to eosinophils } \\
\text { Direct antimicrobial effect }\end{array}$ \\
\hline C3a-desArg & 8 & $\begin{array}{l}\text { Inactivated derivative of C3a } \\
\text { Chemotactic to eosinophils } \\
\text { Direct antimicrobial effect }\end{array}$ \\
\hline C3b & 178 & $\begin{array}{l}\text { Larger fragment formed by cleavage of } \mathrm{C} 3 \text { during activation } \\
\text { Component of the alternative pathway } \mathrm{C} 3 \text { convertase } \mathrm{C} 3 \mathrm{bBb} \\
\text { Component of the } \mathrm{C} 5 \text { convertases } \mathrm{C} 4 \mathrm{~b} 2 \mathrm{a} 3 \mathrm{~b} \text { and } \mathrm{C} 3 \mathrm{~b}_{\mathrm{n}} \mathrm{Bb} \\
\text { Opsonin and ativation regulator through binding to } \mathrm{CR} 1\end{array}$ \\
\hline ic3b & 176 & $\begin{array}{l}\text { Degradation fragment formed by cleavage of C3b } \\
\text { Opsonin through binding to CR3 (CD11b-CD18; integrin } \alpha_{M} \beta_{2} \text { ), } \\
\text { CR4 (CD11C-CD18; integrin } \alpha_{x} \beta_{2} \text { ) and possibly to CR1 }\end{array}$ \\
\hline $\mathrm{c} 3 \mathrm{c}$ & 138 & Degradation fragment formed by cleavage of $\mathrm{C} 3 \mathrm{~b}$ \\
\hline $\mathrm{C} 3 \mathrm{~d} / \mathrm{dg}$ & 33-38 & $\begin{array}{l}\text { Degradation fragment formed by cleavage of C3b containing } \\
\text { the C } 3 \mathrm{~b} \text { covalent binding site } \\
\text { Binds to CR2 and regulates B-cell function }\end{array}$ \\
\hline C4a & 8 & $\begin{array}{l}\text { Smaller fragment formed by cleavage of } \mathrm{C} 4 \text { during activation } \\
\text { Complement anaphylatoxin }\end{array}$ \\
\hline $\mathrm{C} 4 \mathrm{~b}$ & 192 & $\begin{array}{l}\text { Larger fragment formed by cleavage of } \mathrm{C} 2 \text { during activation } \\
\text { Component of the classical pathway } \mathrm{C} 3 \text { convertase } \mathrm{C} 4 \mathrm{~b} 2 \mathrm{a} \\
\text { Opsonin and activation regulator through binding to CR1 }\end{array}$ \\
\hline $\mathrm{C5a}$ & 11 & $\begin{array}{l}\text { Smaller fragment formed by cleavage of } \mathrm{C} 5 \text { during activation } \\
\text { Complement anaphylatoxin } \\
\text { Chemotactic to neutrophils and monocytes } \\
\text { Induces apoptosis }\end{array}$ \\
\hline C5a-desArg & 11 & $\begin{array}{l}\text { Inactivated derivative of C5a } \\
\text { Chemotactic to neutrophils and monocytes }\end{array}$ \\
\hline C5b & 185 & $\begin{array}{l}\text { Larger fragment formed by cleavage of } \mathrm{C} 5 \text { during activation } \\
\text { Component of the membrane attack complex } \mathrm{C} 5 \mathrm{~b}-\mathrm{C} \mathrm{g}_{\mathrm{n}}\end{array}$ \\
\hline $\mathrm{Ba}$ & 30 & Smaller fragment formed by cleavage of factor B \\
\hline $\mathrm{Bb}$ & 63 & $\begin{array}{l}\text { Larger fragment formed by cleavage of factor } \mathrm{B} \\
\text { Component of the alternative pathway } \mathrm{C} 3 \text { convertase } \mathrm{C} 3 \mathrm{bBb} \\
\text { and } \mathrm{C} 5 \text { convertase } \mathrm{C} 3 \mathrm{~b}_{\mathrm{n}} \mathrm{Bb} \\
\text { Induces apoptosis }\end{array}$ \\
\hline
\end{tabular}

Abbreviations: $\mathrm{CR}$, complement receptor; $\mathrm{MW}$, molecular weight. to inflammation and tissue damage in IC-mediated manifestations, with histopathological findings of complement deposits correlating with clinical symptoms and complement consumption in the circulation. However, seemingly in paradox, complement deficiency states within the classical pathway are associated with a high risk of developing SLE. This dualism is often referred to as 'the lupus paradox', and has previously been discussed by Müller-Eberhard ${ }^{5}$ and by Carroll. ${ }^{6}$ We hypothesize that the lupus paradox reflects the complexity of complement-mediated functions; factors derived from $\mathrm{C} 3$ and components downstream in the activation sequence cause or promote the cell and tissue damage associated with SLE, whereas initial development of the disease is particularly influenced by deficiencies within the initiating components of the classical pathway, which do not protect from complement-mediated damage. The evidence that supports this theory is discussed in more detail in the following sections.

\section{Complement deficiency and disease}

The occurrence of complete deficiency of a complement protein is a relatively rare finding; nevertheless, deficiency syndromes have been described for most components (Table 3). Complement deficiency states are associated with increased susceptibility to various forms of infections. ${ }^{7}$ Deficiencies of classical pathway complement proteins $\mathrm{C} 1 \mathrm{q}, \mathrm{C} 1 \mathrm{r}$ or $\mathrm{C} 1 \mathrm{~s}, \mathrm{C} 2$ and $\mathrm{C} 4$ are associated with an increased frequency of pyogenic infections, ${ }^{7}$ and also SLE and SLE-like disorders. ${ }^{8}$ A clear hierarchy exists in regards to susceptibility to SLE conferred by various complementdeficiency syndromes, with deficiencies of $\mathrm{C} 1 \mathrm{q}$ and of C1r or C1s associated with a high risk (90\%) and C4 deficiency a slightly lower risk, whereas individuals with C2 deficiency have an estimated 10-20\% risk of developing the disease. ${ }^{8}$ The results of some studies have suggested an association of MBL deficiency with increased susceptibility to SLE, ${ }^{9}$ but no evidence of increased SLE risk was found in an epidemiologically-based investigation. ${ }^{10}$ Clear evidence of an increased SLE risk has not been found in individuals with heterozygous C2 deficiency, ${ }^{11}$ or in individuals with a polymorphic variant of the $\mathrm{C} 1 \mathrm{q}$ subunit $\mathrm{A}$ encoding gene, which is associated with decreased C1q levels; ${ }^{12}$ however, a possible association of this $\mathrm{C} 1 \mathrm{q}$ variant with subacute cutaneous lupus erythematosus has been reported. ${ }^{12}$

Genes encoding the complement components that constitute the $\mathrm{C} 3$ convertases- $\mathrm{C} 2, \mathrm{C} 4$ and complement factor $\mathrm{B}$-are located in the MHC class III region on chromosome 6 . The gene encoding $\mathrm{C} 4$ protein is extremely polymorphic, and has been ancestrally duplicated and mutated in the human genome to create two coding gene variants, $C 4 A$ (encoding acidic $\mathrm{C} 4 \mathrm{~A}$ ) and $C 4 B$ (encoding basic $\mathrm{C} 4 \mathrm{~B}$ ). Furthermore, dichotomous long and short forms of both $C 4 A$ and $C 4 B$ genes also exist, owing to the integration of a human endogenous retrovirus, HERV-K(C4). ${ }^{13}$ Moreover, between one and four copies of the genes encoding either C4 isotype - and in the long or short form-can be present on each chromosome; thus, a range of 2-8 copies of $\mathrm{C} 4$ genes can theoretically be present, although 0-7 copies have been documented in the diploid genome. ${ }^{13}$ Functional differences between C4A and C4B isotypes have been suggested to influence the risk of developing SLE and severity of the disease. Activated C4A preferentially forms amide bonds with protein antigens, whereas $\mathrm{C} 4 \mathrm{~B}$ has a propensity to form ester linkages with carbohydrate antigens, such as those found on bacterial cell walls. ${ }^{14}$ Homozygous deficiency of C4A has been suggested to be a susceptibility factor for SLE, ${ }^{15}$ potentially related to impaired scavenging of ICs in the absence of C4A. No clear disease association to $\mathrm{C} 4$ gene copy variation has been shown.

Complement deficiencies affecting the classical pathway-genetically determined or acquired as a result of complement component consumption-are strongly associated with an increased risk of SLE, as stated above, 
but not with autoimmune diseases in general. Thus, no indications exist for increased risk of developing other systemic autoimmune diseases, such as rheumatoid arthritis (RA) or systemic vasculitis, in individuals with complement deficiency. The reason for the association between complement deficiencies, particularly in the classical pathway, and risk of developing SLE or SLE-like disorders is not clear, but four hypotheses can be identified (Figure 2); the data that support these theories are discussed in the following sections.

\section{Impaired handling of ICs}

A well-documented finding is that complement deficiency reduces the capacity to solubilise ICs. ${ }^{16,17} \mathrm{Com}-$ plement solubilisation of ICs mediates their transport from tissues to the reticuloendothelial system via interaction with blood cells expressing complement receptors. ${ }^{16}$ Kinetic studies have demonstrated the importance of the classical pathway for effective opsonization of ICs, ${ }^{17}$ which enables efficient recognition of such materials and their removal from the circulation.

\section{Aberrant induction of tolerance}

Defective induction of immune tolerance is another hypothesis-based mainly on data from animal models - that might explain the association of complement deficiencies with SLE or SLE-like disorders. ${ }^{18}$ Self antigens are coated with complement fragments and delivered to the specific B cells by binding to complement receptors thereby enhancing the elimination of the selfreactive cells. Complement deficiency could thus lead to inefficient elimination of self-reactive B cells, which, in the presence of T-helper cells, could be activated to produce autoantibodies. Presumably, autoreactive T cells could also contribute to defective immune tolerance and increased autoantibody production.

\section{Deficient scavenging of apoptotic cells}

In the late 1990s, the complement system was found to be involved in scavenging of apoptotic cells; in 1997, Korb and Ahearn ${ }^{19}$ demonstrated that $\mathrm{C} 1 \mathrm{q}$ can bind directly to apoptotic cellular material in absence of antibodies. Data from a study in $\mathrm{Clq}$ knockout mice published the following year ${ }^{20}$ suggested that the role of complement in clearance of apoptotic material explained the relationship between deficiencies in classical pathway components and the risk of developing SLE. Delayed clearance of apoptotic cells can lead to secondary necrosis, which could increase tissue inflammation and activation of selfreactive $\mathrm{B}$ cells and $\mathrm{T}$ cells. We have shown in an in vitro model that $\mathrm{C} 1 \mathrm{q}$ was not more important for clearance of apoptotic cells than other components of the classical pathway and that components of the alternative and lectin activation pathways had less influence on the phagocytosis of such material. ${ }^{21}$

\section{Deficient control of cytokine production}

Studies have indicated that complement components are important regulators of cytokine production. ${ }^{22}$ For example, our group found that $\mathrm{C} 1 \mathrm{q}$ is able to inhibit or
Table 2 | Complexes formed during complement activation

\begin{tabular}{|c|c|}
\hline Complex & Description and/or function \\
\hline $\mathrm{C} 1 \mathrm{INH}-\mathrm{C} 1 \mathrm{r}-\mathrm{C} 1 \mathrm{~s}$ & Intermediate complex formed during activation of C1 \\
\hline $\mathrm{C}_{1} \mathrm{NHH}_{2}-\mathrm{C} 1 \mathrm{r}-\mathrm{C} 1 \mathrm{~s}$ & Complex formed during activation of $\mathrm{C} 1$ \\
\hline $\mathrm{c} 4 \mathrm{~b} 2 \mathrm{a}$ & C3 convertase of the classical pathway \\
\hline $\mathrm{c} 4 \mathrm{~b} 2 \mathrm{a} 3 \mathrm{~b}$ & C5 convertase of the classical pathway \\
\hline $\mathrm{C} 3 \mathrm{bBb}$ & C3 convertase of the alternative pathway \\
\hline $\mathrm{C} 3 \mathrm{~b}_{\mathrm{n}} \mathrm{Bb}$ & C5 convertase of the alternative pathway \\
\hline$c 5 b-8$ & Incomplete membrane attack complex \\
\hline $\mathrm{C} 5 \mathrm{~b}-9_{\mathrm{n}}$ & $\begin{array}{l}\text { Membrane attack complex, which induces cell proliferation } \\
\text { and apoptosis }\end{array}$ \\
\hline C5b-9-S & $\begin{array}{l}\text { Membrane attack complex with protein S (membrane } \\
\text { attack inhibited) } \\
\text { Soluble terminal complement complex }\end{array}$ \\
\hline
\end{tabular}

augment the in vitro production of IFN- $\alpha$ - a key cytokine in the pathogenesis of SLE-by peripheral blood mononuclear cells or plasmacytoid dendritic cells (pDCs), depending on the stimulus used; ${ }^{23}$ notably, IFN- $a$ secretion in response to $\mathrm{CpG}$ DNA and ICs in pDCs was inhibited by $\mathrm{C} 1 \mathrm{q}$, whereas $\mathrm{C} 2$ and $\mathrm{C} 4$ did not have this effect. ${ }^{23}$ Together, the findings discussed provide potential explanations for the hierarchy that exists among deficiency states within the classical pathway in regards to the development of SLE.

\section{Complement activation in disease}

Activation of the complement system results in the production of a series of phlogistic proteins with potent biological effects. This process is usually an important defence mechanism, but can turn into a pathogenetic mechanism if not properly regulated and/or when autoantibody formation is intense, owing to formation of ICs in tissues or entrapment of circulating ICs. Aberrant complement activation has been demonstrated to be of importance in several rheumatic diseases such as SLE, RA and systemic vasculitis.

\section{Systemic rheumatic disorders}

The idea that complement activation is involved in the pathogenesis of SLE originates from observations of consumption of complement components, especially those of the classical pathway, in this disease (Figure 2). Complement consumption can manifest as decreased levels of the proteins in the circulation and also increased complement and immunoglobulin deposits in affected organs, such as the kidneys and skin; investigations of these organs form the basis of most studies on SLE pathogenesis. SLE is characterized by breakdown of tolerance against nuclear self antigens, which probably originate from the nuclei of dying cells, and associated proteins. ICs containing such antigens are deposited in different parts of the body and promote inflammation and tissue damage. Furthermore, chronic activation of pDCs by ICs and subsequent production of type I interferons (IFNs) seems to be central to the pathogenesis of SLE. ${ }^{24}$ Strong support for pathogenetic effects of complement in SLE comes from correlations between clinical findings and the 
Table 3 | Summary of complement deficiencies in humans

\begin{tabular}{|c|c|c|c|}
\hline $\begin{array}{l}\text { Complement } \\
\text { component involved }\end{array}$ & Frequency & Main disease association(s) & Reference(s) \\
\hline $\mathrm{C} 1 \mathrm{q}$ & 50-100 reported cases & SLE; glomerulonephritis; infections & Skattum et al. ${ }^{7}$ \\
\hline $\mathrm{C} 1 \mathrm{r}$ or $\mathrm{C} 1 \mathrm{~s}$ & $10-50$ reported cases & SLE; glomerulonephritis & Wu et al. ${ }^{106}$ \\
\hline $\begin{array}{l}\text { C2 } \\
\text { C3 } \\
\text { C4 } \\
\text { MBL } \\
\text { Factor D }\end{array}$ & $\begin{array}{l}\text { Estimated prevalence } 1 / 20,000 * \\
20-50 \text { reported cases } \\
20-50 \text { reported cases } \\
\text { Estimated prevalence } 1 / 10 * \\
<20 \text { reported cases }\end{array}$ & $\begin{array}{l}\text { SLE; infections } \\
\text { SLE; glomerulonephritis; recurrent infections } \\
\text { SLE; glomerulonephritis; infections } \\
\text { Susceptibility to infections } \\
\text { Neisserial infections }\end{array}$ & Skattum et al. ${ }^{7}$ \\
\hline Properdin & 50-100 reported cases & Meningococcal disease & Fijen et al. ${ }^{107}$ \\
\hline $\mathrm{C} 5, \mathrm{C} 6, \mathrm{C} 7$ or $\mathrm{C} 8$ & 20-100 reported cases & Usually healthy; recurrent neisserial infections & Skattum et al. ${ }^{7}$ \\
\hline c9 & $\begin{array}{l}<10 \text { reported cases } \\
\text { Estimated prevalence } 1 / 1,000^{\ddagger}\end{array}$ & Usually healthy & $\begin{array}{l}\text { Skattum et al. } \\
\text { Witzel-Schlömp et al. }{ }^{108}\end{array}$ \\
\hline C1Inh & Estimated prevalence $1 / 50,000^{\$}$ & Hereditary angioedema & Skattum et al. ${ }^{7}$ \\
\hline
\end{tabular}

presence of immune deposits in affected tissues, associations between circulating, deposited and eluted ICs, and from a large number of animal studies. ${ }^{25}$

\section{Complement activation in lupus nephritis}

Immunoglobulins against double-stranded DNA (anti-dsDNA antibodies) are generally accepted to be involved in the pathogenesis of lupus nephritis in most cases; ${ }^{26}$ for example, anti-dsDNA antibodies have been eluted from affected kidneys in experiments involving animal models of lupus. ${ }^{27}$ However, uncertainty remains regarding the extent of IC deposition from circulation compared with local formation resulting from crossreactions between anti-dsDNA antibodies and $\alpha$-actinin, laminin or other glomerular constituents. ${ }^{28}$ Anti-dsDNA antibodies binding to nucleosomes that are trapped in glomeruli by aberrantly expressed laminins or other glomerular constituents has been proposed as a mechanism of IC formation in lupus nephritis. ${ }^{29}$ That initial lesions in kidneys involved in SLE are seen in glomeruli is well established, with the most pronounced immune deposits being observed in proliferative glomerulonephritis (diffuse global glomerulonephritis; WHO grade IV or the International Society of Nephrology-Renal Pathology Society's [ISN-RPS] IV-G classification). ${ }^{30}$ In lupus nephritis in particular, these morphological characteristics are associated with decreased plasma levels of C1q, C2, C4 and often C3 (especially in severe nephritis), ${ }^{31}$ suggesting the pathogenetic mechanism involves IC-mediated activation via the classical pathway. In focal or segmental glomerulonephritis (WHO grade III or ISN-RPS classification IV-S), IC-containing deposits may be scarce or even absent; ${ }^{32}$ thus, the pathogenesis has been suggested to be different from that of diffuse global nephritis and possibly more analogous to the pauci-immune nephritis seen in patients with systemic vasculitis.

\section{Complement proteins as autoantigens}

Evidence suggests that complement components might also be targets of autoantibody responses, which are usually directed against modified proteins and not native components. Anti-C1q antibodies are seen in approximately $30-40 \%$ of patients with SLE and especially in patients with proliferative nephritis. ${ }^{33} \mathrm{C} 1 \mathrm{q}$-specific IgGs recognise the collagenous portions of $\mathrm{Clq}$ molecules that present as a neoepitope on protein binding, and which are not exposed on fluid-phase C1q. ${ }^{34}$ Indeed, evidence suggests that anti-C1q antibodies can be involved in the pathogenesis of lupus nephritis by binding to solid-phase C1q present locally in the kidney, including C1q bound to early apoptotic cells. ${ }^{35,36}$ In addition, antibodies against C1s and C1Inh have been reported in patients with SLE, but the potential pathogenetic effects of these autoantibodies have not been defined. C3 and C4 nephritic factors are IgG autoantibodies with the capacity to stabilize C3 convertases of the classical and alternative pathways, and could therefore be involved in the pathogenesis of nephritis. ${ }^{37}$ Autoantibodies against complement regulators and receptors have been reported, and functional deficiency caused by antibodies against complement factor $\mathrm{H}$ has been suggested to be of clinical importance in nephritis based on data from animal models. ${ }^{38}$

\section{Complement and microparticles in SLE}

Increased complement activation through the classical pathway in SLE has also been reported to be reflected in the composition of cell-derived microparticles. ${ }^{39}$ Increased loads of IgG, IgM and C1q were seen on microparticles derived from patients with SLE compared with those from patients with RA or systemic sclerosis, or from healthy individuals. ${ }^{39}$ The microparticles could be a source of immunogenic autoantigens that are accessible for autoantibody binding, and IC formation on these particles might contribute to complement activation in SLE.

\section{Complement and neutrophil activation}

Observations made in a number of studies give support to a possible role for neutrophil extracellular traps (NETs) - structures with bactericidal activity comprising chromatin fibres and other cellular components-in the pathogenesis of SLE and especially lupus nephritis. Complement activation with subsequent $\mathrm{C} 5 \mathrm{a}$ 
anaphylatoxin chemotactic receptor (C5aR) involvement primes viable neutrophils to undergo NETosis-a specialised form of cell death-where the neutrophils expel NETs into the extracellular environment. ${ }^{40}$ NETs are a potential source of autoantigens such as DNA, and impaired degradation of these structures, which is partially dependent on anti-NET antibodies, seems to be strongly associated with kidney involvement in SLE. ${ }^{41}$ In addition, CR3 (CD11b-CD18; integrin $\alpha_{M} \beta_{2}$ ), which mediates neutrophil activation, has been suggested to be of importance. ${ }^{42}$ Furthermore, NETs might activate pDCs in SLE, by presenting self-DNA-peptide complexes that interact with Toll-like receptor 9 in these cells..$^{43}$ Thus, a role for complement in regulation of NET formation or breakdown could be of pathogenetic importance in SLE and SLE-like disorders.

Complement split products have been reported to activate neutrophils and platelets (through mechanisms similar to those that promote NETosis in the former), resulting in occlusive vasculopathy owing to their aggregation and adherence to vascular endothelial cells. ${ }^{44-46}$ Moreover, evidence suggests that stimulation with C5a, as well as MAC formation, might cause cells to release microparticles with procoagulant activities. ${ }^{46}$ More recently, C4d deposits have been reported on red blood cells after incubation with sera from patients with SLE, but not with control sera. ${ }^{47}$ These deposits were associated with biochemical changes in the erythrocyte and decreased cell membrane deformability, ${ }^{47}$ which could conceivably affect the microcirculation and impair delivery of oxygen to tissues. The complement-mediated effects on the vasculature described above could contribute to SLE manifestations including central nervous system ischemia, pulmonary vasculitis and pancreatitis.

\section{C-reactive protein and complement activation}

The classical pathway can be activated not only by targetbound antibodies or ICs but also by breakdown products of apoptotic cells, C-reactive protein (CRP) and lipopolysaccharides. ${ }^{48}$ These mechanisms of complement activation could be of pathogenetic importance in SLE and might contribute to tissue damage. However, high serum levels of soluble CRP have been shown to inhibit complement activation. ${ }^{49}$ The clinical relevance of this finding is unclear, as disparate results have been obtained with CRP supplementation in mouse lupus models. ${ }^{50,51}$

\section{Complement in antiphospholipid syndrome}

Antiphospholipid syndrome (APS) is closely related to SLE, and is a condition in which pathogenic, complement-activating antibodies target various phospholipids and phospholipid-binding proteins that have an essential role in homeostasis of the coagulation system..$^{52}$ The importance of complement activation to the pathogenesis of APS has been shown in relevant animal models ${ }^{52,53}$ for example, reduced thrombus generation and foetal loss has been demonstrated in a mouse model of APS after inhibition of C3 convertase using a soluble CR1-related protein y (Crry)-immunoglobulin chimera. ${ }^{53}$ Furthermore, patients with SLE associated

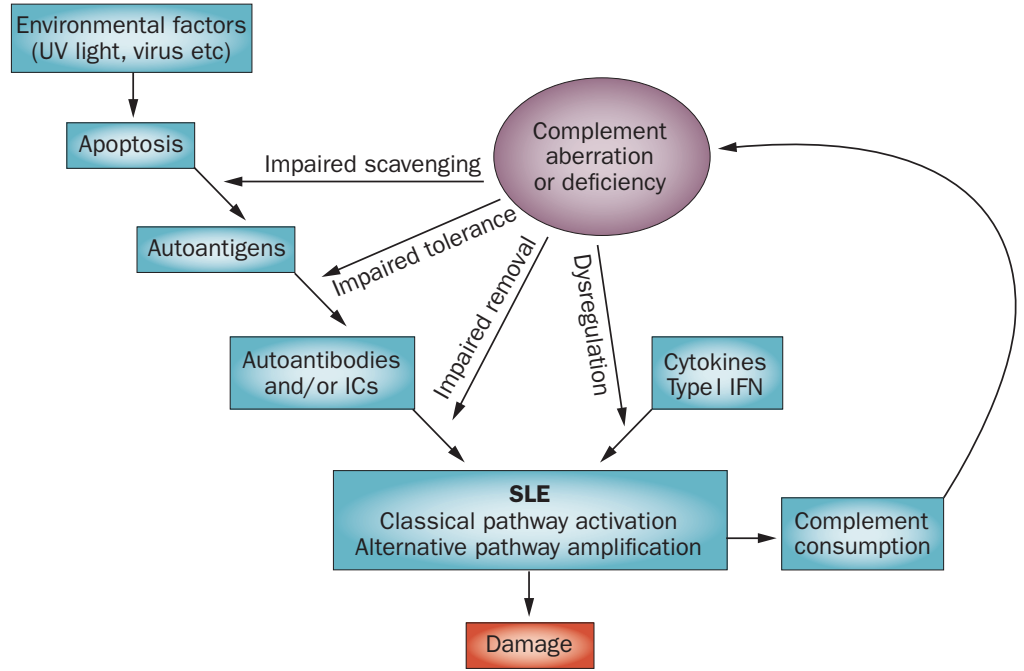

Figure 2 | Complement in the pathogenesis of SLE. Evidence suggests that autoantigens derived from apoptotic cells, and possibly also neutrophil extracellular traps and microparticles, are involved in the generation of autoantibodies that underlie the pathogenesis of SLE. In a genetically predisposed individual, these processes are thought to give rise to a sustained immune reaction resulting in the disease. Deficiency or aberrations in components of the classical pathway of complement activation, either genetically determined or caused by excessive activation and consumption, might be part of the pathogenetic process on multiple levels: impaired scavenging of autoantigens; compromised immune tolerance to self antigens; defective autoantibodies and IC removal; and dysregulated cytokine production. Increased complement activation, as well as causing complement consumption and deficiency, can participate in tissue damage such as glomerulonephritis, which is a hallmark of SLE. Such damage provokes further inflammation and additional complement aberrations, which could contribute to a vicious circle of reactions preventing termination of the disease process. Abbreviations: IC, immune complex; IFN, interferon; SLE, systemic lupus erythematosus; UV, ultraviolet.

with C2 deficiency seem to be protected from thrombotic events, despite the presence of antiphospholipid antibodies in a large proportion of these individuals. ${ }^{54}$

\section{Complement-mediated tubulointerstitial damage}

Vascular and tubulointerstitial damage are of utmost importance for prognosis in SLE-associated kidney disease. The involvement of complement activation in tubulointerstitial inflammation and damage, including demonstration of a pathogenetic effect of C5aR signalling, has been demonstrated in animal models. ${ }^{55} \mathrm{In}$ $\mathrm{MRL}^{l p r}$ mice, complement factor $\mathrm{H}$ deficiency clearly accelerates the development of lupus nephritis, in terms of both glomerular and tubulointerstitial inflammation. ${ }^{56}$ Interestingly, although no mutations in genes encoding complement regulatory proteins have yet been shown to predispose individuals to SLE or nephritis, MCP and complement factor $\mathrm{H}$ polymorphisms have been associated with age at onset of lupus nephritis. ${ }^{57}$

\section{Complement involvement in skin manifestations}

Complement is involved in various skin manifestations of SLE, and is usually found deposited in the dermoepidermal junction together with immunoglobulins of all major classes (IgG, IgM and IgA).$^{58}$ DNA released from keratinocytes after ultraviolet-light-induced injury might 


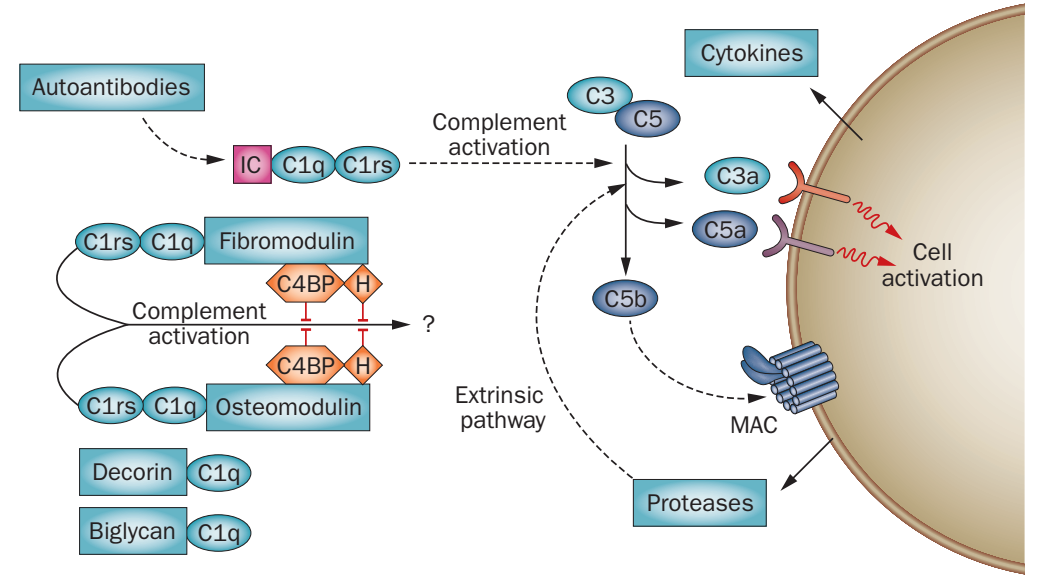

Figure 3 | Complement in the pathogenesis of rheumatoid arthritis. In the synovial compartment ICs are formed, comprising various autoantibodies and autoantigens. These complexes activate complement leading to generation of proinflammatory complement fragments and complexes, which interact with cells causing release of cytokines and proteases. Activation of $\mathrm{C} 5$ seems to be most important in driving the damaging inflammation. Some proteases might be able to cleave C3 and thereby increase complement activation (extrinsic pathway). Several extracellular matrix proteins interact with complement and could modulate these processes. Fibromodulin and osteomodulin (also known as osteoadherin) bind $\mathrm{C} 1 \mathrm{q}$ and can initiate classical pathway activation, but bind also C4BP and complement factor $\mathrm{H}$, which inhibit complement activation. Decorin and biglycan might also modulate complement activation by binding $\mathrm{C} 1 \mathrm{q}$ without initiating activation. Abbreviations: C4BP, C4b-binding protein; $\mathrm{H}$, complement factor $\mathrm{H}$; IC, immune complex; MAC, membrane attack complex.

bind type IV collagen and serve as antigen for antinuclear antibodies. ${ }^{59,60}$ In patients with SLE, linear immunoglobulin and complement containing deposits similar to those found in skin lesions are often also found in uninvolved skin, a feature that can be useful for diagnosis.

\section{Complement in Sjögren's syndrome pathogenesis} Sjögren's syndrome (SS) is an autoimmune disorder closely related to, and often coexisting with, SLE and other inflammatory connective tissue disorders. As in SLE, null alleles for C4A are common. ${ }^{61}$ The presence of these null alleles is a common reason for observation of slightly lower than normal C4 serum levels in patients with SS and/or SLE. ${ }^{61}$ Both in patients with SLE ${ }^{62}$ and individuals with $\mathrm{SS},{ }^{63}$ slightly low levels of $\mathrm{C} 4 \mathrm{BP}$ are often recorded during periods of active disease.

\section{Complement in myositis and systemic sclerosis}

A proposed initial event in the pathogenesis of dermatomyositis and polymyositis is the activation of complement in response to antibodies directed against endothelial cells and subsequent MAC formation; ${ }^{64}$ deposits of $\mathrm{C} 3 \mathrm{~b}, \mathrm{C} 4 \mathrm{~b}$ and MAC are found on capillaries and could be related to muscular ischemia and capillary loss. ${ }^{64}$ Hypocomplementaemia-possibly resulting from increased complement-component consumption-in dermatomyositis, polymyositis and systemic sclerosis is preferentially seen in patients with manifestations that overlap with other diseases, especially SLE. Nevertheless, evidence suggests that complement activation related to dysfunction of regulatory proteins could contribute to the inflammatory process and vascular damage in these diseases. ${ }^{65}$

\section{Rheumatoid arthritis and other arthritides Evidence of a role for complement in RA}

The evidence for complement activation as a mediator of joint and extra-articular inflammation in RA is strong. Interestingly, the results of a 2011 study suggest that increased serum levels of $\mathrm{C1q}$, caused by genetic variation, could increase the risk of developing RA, possibly owing to increased capacity for activation via the classical pathway ${ }^{66}$ Moreover, a role for local intra-articular activation of complement in RA is supported by observation of decreased total haemolytic complement activity and reduced levels of individual components in synovial fluid. ${ }^{67,68}$ Studies of complement component cleavage products supported this interpretation. ${ }^{69}$ On the other hand, patients with spondyloarthritis, who have less-erosive arthritic manifestations, usually do not show evidence of overt complement activation. ${ }^{70}$

Findings in mouse models of inflammatory arthritis have revealed that complement is critically involved in inflammatory joint damage. ${ }^{71} \mathrm{C} 5 \mathrm{a}$ has been implicated as an important mediator of joint injury; therefore, C5aneutralizing antibodies would be expected to counteract development of disease. Indeed, a vaccine inducing anti-C5a antibodies-which do not markedly compromise $\mathrm{C} 5$ or $\mathrm{C} 5 \mathrm{~b}$ activity - has been proven effective in the prevention of antibody-mediated C5a-dependent inflammatory disease in mouse models. ${ }^{72}$

\section{Mechanism of complement-mediated damage in RA}

An overview of the pathogenetic complement-dependent process that might be involved in RA is provided in Figure 3. In patients with RA, a wide range of autoantibodies can be present, many of which are able to bind to joint antigens and form ICs in the inflamed synovial tissue (pannus) and cartilage, resulting in complement activation and consumption of complement components. As a consequence, activation products such as C1Inh-C1r-C1s complexes, C2a, C3a, C3d or C3dg and $\mathrm{C} 5 \mathrm{a}$ are found at increased levels in synovial fluid. ${ }^{70,71}$ Furthermore, complement deposition can be demonstrated in the synovial tissue by immunohistological staining. ${ }^{73}$ These complement proteins attract and activate macrophages, mast cells, fibroblasts and neutrophils, with subsequent release of proteolytic enzymes leading to tissue damage. The MAC can probably potentiate the inflammatory process by stimulation of collagenase production and release by fibroblasts (Figure 3), as indicated by the results of in vitro studies. ${ }^{74}$ Indeed, findings from a mouse model have implicated effector mechanisms initiated by C3aR, C5aR and MAC in the pathogenesis of RA. ${ }^{75}$

\section{Complement activation pathways in RA}

Synovial fluid from patients with RA contain microparticles originating from apototic granulocytes, ${ }^{76}$ which can potentially activate the classical pathway in a similar way to circulating ICs. Thus, C1q, C3 and C4 deposits 
are found on microparticles, ${ }^{76}$ and correlations are found between circulating ICs and classical pathway activation products in synovial fluid, ${ }^{76,77}$ suggesting a role for microparticles and complement activation in joint pathology. High levels of $\mathrm{Bb}$ fragments have also been found in synovial fluids from patients with $\mathrm{RA},{ }^{78}$ providing evidence that activation of the alternative pathway might be involved in the pathogenesis of this disease.

Citrullinated proteins produced by post-translational protein modification, in which arginine residues are converted to citrulline, seem to be immunogenic and thereby arthritogenic. Citrullinated proteins and antibodies against these proteins are frequently observed in synovial tissue from patients with RA. ${ }^{79}$ Consistent with these findings are observations that anti-cyclic citrullinated peptide (anti-CCP) antibodies activate both the classical and alternative pathways of the complement system. ${ }^{80}$ In addition, type II collagen ${ }^{81}$ and IgA-containing ICs ${ }^{82}$ might be activators of the alternative pathway in RA. Of importance is the realization that the alternative pathway acts as an amplification loop of classical pathway activation (Figure 1), and thus these mechanisms could potentially exacerbate complement-mediated injury in RA. As is the case for SLE, ${ }^{9}$ limited evidence exists to suggest that the lectin pathway is of importance in the pathogenesis of RA; however, MBL deficiency seems to contribute to RA severity, showing an association with increased risk of erosive disease. ${ }^{83}$

A number of cartilage molecules have been identified that bind complement proteins. Examples are decorin and biglycan, which bind but do not activate C1q (Figure 3). By contrast, fibromodulin and osteomodulin (also known as osteoadherin) bind to collagen fibres in cartilage and interact with the globular heads of C1q, leading to activation of the classical pathway; ${ }^{84,85}$ however, these proteins also bind C4BP and complement factor $\mathrm{H}$, which limits complement activation to the early part of the classical pathway (Figure 3) ${ }^{84,85}$ Nevertheless, low-level complement activation might contribute to chronic inflammation in the damaged joint. On the other hand, findings suggest that decorin, biglycan and possibly cartilage oligomeric matrix protein (COMP) inhibit $\mathrm{C} 1$ activation, which could be protective. ${ }^{86,87}$ COMP also binds MBL, inhibiting the lectin pathway, but might activate the alternative pathway by interacting with properdin and C3, which could be of importance for development of cartilage and bone damage in RA. ${ }^{87}$ Indeed, COMP-C3b complexes have been detected in sera from patients with RA, and have been implicated as markers of this disease. ${ }^{87}$

\section{Extra-articular disease and other arthritides}

$\mathrm{RA}$ is a heterogeneous disease and is associated with extra-articular manifestations, which have an important influence on the outcome of the disease. In rheumatoid systemic vasculitis in particular, complement activation by ICs deposited in the affected tissues is of pathogenetic importance. ${ }^{88}$ Furthermore, hypocomplementaemia, with decreased C3 and C4 plasma levels suggestive of increased complement activation, is commonly observed in patients with severe extra-articular manifestations, such as mononeuritis multiplex. ${ }^{89}$

Studies of complement activity in other arthritides, such as psoriatic arthritis, ankylosing spondylitis and reactive arthritis, are relatively scarce. Evidence of complement activation in osteoarthritis (OA) and spondyloarthritis -increased amounts of C1Inh-C1r-C1s complexes and C3d fragments and decreased levels of C3 and C4-was not found in synovial fluid in a study by Sjöholm and co-workers, ${ }^{70}$ despite clear evidence of inflammation. Another report supported these observations, ${ }^{73}$ and demonstrated marginal involvement of complement in reactive arthritis, with local deposition of C3b and C9 in synovial tissue. ${ }^{73}$ By contrast, a 2011 study demonstrated the importance of complement activation in the pathogenesis of OA, as components of the classical pathway, alternative pathway, and the MAC were found to be aberrantly expressed in patients with this disease $;{ }^{90}$ the authors suggested that extracellular matrix proteins, such as fibromodulin, could contribute to this process. ${ }^{90}$ Increased formation of MAC resulted in stimulation of chondrocytes to produce proinflammatory factors and matrixdegrading enzymes in vitro, and C5 deficiency protected against surgically-induced OA in a mouse model..$^{90} \mathrm{On}$ the basis of these findings, individuals with reduced functional activity of complement regulatory proteins could potentially have an increased risk of developing $\mathrm{OA}$, as a result of increased $\mathrm{C} 3$ and $\mathrm{C} 5$ activation.

\section{Systemic vasculitis}

A number of studies have shown that complement is involved in the pathogenesis of systemic vasculitis. Strong evidence demonstrating the importance of the alternative pathway in the pauci-immune process of antineutrophil cytoplasmic autoantibody (ANCA)-associated vasculitis has been obtained from relevant animal models. Mice lacking $\mathrm{C} 5$, complement factor $\mathrm{B},{ }^{91}$ or $\mathrm{C} 5 \mathrm{aR}^{92}$ are protected from anti-myeloperoxidase IgG-induced glomerulonephritis, and inhibition of C5 activation using an anti-C5 antibody ameliorated disease in this model.${ }^{93}$ Furthermore, C3a and C5a were generated from normal serum by supernatants produced by TNF-primed neutrophils stimulated with IgG from patients with ANCA-associated disease, but not with IgG from healthy individuals; $;^{91,92}$ the conditioned supernatants were also able to sensitize neutrophils for ANCA-mediated activation via the $\mathrm{C} 5 \mathrm{aR} .{ }^{92}$ The studies demonstrated that neutrophils primed with low doses of cytokines and coagulation factors show evidence of alternative pathway activation followed by enhanced neutrophil activation and recruitment. On the basis of these findings, complement activation via the alternative pathway has been suggested to be an important positive feedback amplification mechanism in neutrophil-mediated diseases. ${ }^{91,92}$

In patients with Behçet disease, perivascular deposits of complement components $\mathrm{C} 3$ and $\mathrm{C} 4$ are found at high frequency in cutaneous and mucocutaneous lesions. ${ }^{94}$ Furthermore, the deposits are observed in the dermoepidermal junctions within, or in proximity to, skin lesions at a similar frequency as in patients with SLE. ${ }^{4}$ Thus, some 
evidence indicates that complement might be involved in the pathogenesis of Behçet disease, but more studies and support from animal models of this disease are required.

Hypocomplementaemic urticarial vasculitis syndrome (HUVS) is a disorder clinically characterized by erythema, hives, hypocomplementaemia and production of anti-C1q autoantibodies. The disease can be difficult to differentiate from SLE, but anti-C1q autoantibodies obtained from patients with HUVS are usually directed against B-chain and C-chain epitopes of the C1q molecule, whereas in SLE anti-C1q autoantibodies usually target the conformational epitopes in the assembled molecule. ${ }^{95}$ The difference in specificity of these autoantibodies could have implications for complement activation and the pathogenesis of these diseases. ICs containing anti-C1q autoantibodies are found in the circulation of patients with HUVS and activate the classical pathway in blood vessel walls, leading to mast cell degranulation and increased vascular permeability and leukocytoclastic vasculitis. ${ }^{96}$ Anti-C1q autoantibodies can crossreact with lung surfactant factor proteins in both HUVS and SLE, resulting in lung disease. ${ }^{96}$

\section{Complement-directed therapies}

On the basis of data demonstrating an important pathogenetic role of complement in rheumatic diseases and the effects of complement inhibition in animal models, this system has been suggested to be an interesting target for therapy. Two main goals of such therapies are reconstitution in complement-deficiency states and inhibition of complement activation in diseases in which strong evidence suggests that activation causes damage. Other possible aims of complement-targeted therapeutics are strengthening of the defence against certain infections and improvement of antibody responses to vaccines. A detailed discussion of development of complementdirected therapeutics is beyond the scope of this Review and has been reviewed elsewhere. ${ }^{97}$

\section{Complement component supplementation}

Prevention of disease through supplementation of missing complement components has been attempted in various deficiency syndromes. ${ }^{7}$ The most successful results have been obtained with C1Inh concentrate, which is now licensed in many countries and routinely used to correct deficiency of this protein. ${ }^{98}$ Plasma-derived MBL has been tested in patients deficient for MBL, ${ }^{99}$ and this product -as well as recombinant MBL preparations-might be beneficial in carefully selected cases. Patients with $\mathrm{C} 1 \mathrm{q}$ or $\mathrm{C} 2$ deficiency have been treated with regular infusions of plasma and clinical improvements have been reported. ${ }^{100,101}$ In C1q deficiency, another possible method of complement protein supplementation is stem cell transplantation, as $\mathrm{C} 1 \mathrm{q}$ is produced by bone marrow derived cells.

\section{Complement inhibiting agents}

Treatments comprising antibodies that target complement components have been shown to reduce tissue damage after myocardial infarction and stroke, ${ }^{102}$ which are important late organ manifestations in rheumatic diseases. The results of studies using animal models suggest that antibodies that block $\mathrm{C} 5$ and $\mathrm{C} 5 \mathrm{aR}$ activity are promising biologic treatment options in systemic vasculitis ${ }^{103}$ and other rheumatic conditions. ${ }^{104}$

Vaccination has been a successful approach to the prevention of infections in individuals with complement deficiencies, which occur in patients with SLE (Table 3), as discussed above. ${ }^{7}$ Conversely, animal studies suggest that vaccination against complement components could be a future option in prevention of inflammatory rheumatic disorders that are dependent on aberrant complement activation, particularly involving $\mathrm{C} 5 \mathrm{a}$ and $\mathrm{C} 5 \mathrm{aR} .{ }^{72}$ Adjuvant effects of C3d fragments on binding to CR2 receptors on $\mathrm{B}$ cells have been used in vaccine development. ${ }^{105}$

In the near future, complement-directed therapy will probably become an alternative in both acute and chronic clinical disorders, including a number of rheumatic diseases. However, long-term complement inhibition could be complicated by increased risk of infections and potentially autoimmunity. Future developments that enable balanced regulation of complement activation will open avenues towards safe therapeutic control of complement in rheumatic and other diseases.

\section{Conclusions}

Complement activation is of importance in the pathogenesis of several inflammatory and also degenerative rheumatic disorders. Furthermore, deficiency states within the classical pathway are closely associated with, and might predispose to, development of SLE and SLElike disorders, but not to autoimmunity in general. Other complement deficiencies do not increase risk of autoimmune disease, but almost all increase susceptibility to bacterial infections. Local activation of complement in tissues affected by rheumatic diseases, especially via the alternative pathway, is often not reflected in signs of complement activation in body fluids such as blood, and can cause tissue damage that contributes to disease pathology. The increased understanding of complement function in rheumatic and other inflammatory diseases has identified pathways and components of this system as potential therapeutic targets, and initiated the development of potential new treatments.

Review criteria
A large number of potential references were collected
for this Review by searching PubMed, MEDLINE and the
Lund University library database LibHub as well as
the personal collections of the authors. We performed
a systematic review of articles published up to January
2012 using MeSH terms "complement" together
with "systemic lupus erythematosus", "rheumatoid
arthritis", "extraarticular manifestations of rheumatoid
arthritis", "spondylarthropathy", "psoriatric arthritis",
"osteoarthritis", "systemic sclerosis", "polymyositis",
"dermatomyositis", "Sjögren's syndrome", "systemic
vasculitis", "Wegener's granulomatosis", "microscopic
polyangiitis" and "Behcet's disease". The references
were limited to papers published in the English language
and were selected according to relevance to the topic.


1. Medof, M. E., lida, K., Mold, C. \& Nussenzweig, V. Unique role of the complement receptor CR1 in the degradation of $\mathrm{C} 3 \mathrm{~b}$ associated with immune complexes. J. Exp. Med. 156, 1739-1754 (1982).

2. Fearon, D. T. \& Carter, R. H. The CD19/CR2/ TAPA-1 complex of B-lymphocytes: linking natural to acquired immunity. Annu. Rev. Immunol. 13, 127-149 (1995).

3. Carroll, M. C. \& Prodeus, A. P. Linkages of innate and adaptive immunity. Curr. Opin. Immunol. 10, 36-40 (1998).

4. Heeger, P. S. \& Kemper, C. Novel roles of complement in T effector cell regulation. Immunobiology 217, 216-224 (2011).

5. Müller-Eberhard, H. J. Molecular organization and function of the complement system. Annu. Rev. Biochem. 57, 321-347 (1988).

6. Carroll, M. C. The lupus paradox. Nat. Genet. 19, 3-4 (1998).

7. Skattum, L., van Deuren, M., van der Poll, T. \& Truedsson, L. Complement deficiency states and associated infections. Mol. Immunol. 48 , 1643-1655 (2011)

8. Truedsson, L., Bengtsson, A. A. \& Sturfelt, G. Complement deficiencies and systemic lupus erythematosus. Autoimmunity 40, 560-566 (2007)

9. Garred, P., Voss, A., Madsen, H. O. \& Junker, P. Association of mannose-binding lectin gene variation with disease severity and infections in a population-based cohort of systemic lupus erythematosus patients. Genes Immun. 2 , 442-450 (2001)

10. Jönsen, A. et al. Genetically determined mannanbinding lectin deficiency is of minor importance in determining susceptibility to severe infections and vascular organ damage in systemic lupus erythematosus. Lupus 16, 245-253 (2007).

11. Lipsker, D. M. et al. Lupus erythematosus associated with genetically determined deficiency of the second component of the complement. Arch. Dermatol. 136, 1508-1514 (2000).

12. Racila, D. M. et al. Homozygous single nucleotide polymorphism of the complement C1QA gene is associated with decreased levels of $\mathrm{C} 1 \mathrm{q}$ in patients with subacute cutaneous lupus erythematosus. Lupus 12, 124-132 (2003).

13. Yu, C. Y. \& Whitacre, C. C. Sex, MHC and complement $\mathrm{C} 4$ in autoimmune diseases. Trends Immunol. 25, 694-699 (2004).

14. Law, S. K. \& Dodds, A. W. The internal thioester and the covalent binding properties of the complement proteins C3 and C4. Protein Sci. 6 263-274 (1997)

15. Sturfelt, G. et al. Homozygous C4A deficiency in systemic lupus erythematosus-analysis of patients from a defined population. Clin. Genet 38, 427-433 (1990).

16. Davies, K. E., Peters, A. M., Beynon, H. L. \& Walport, M. J. Immune complex processing in patients with systemic lupus erythematosus. In vivo imaging and clearance studies. J. Clin. Invest. 90, 2075-2083 (1992).

17. Sturfelt, G., Nived, O. \& Sjöholm, A. G. Kinetic analysis of immune complex solubilization: complement function in relation to disease activity in SLE. Clin. Exp. Rheumatol. 10, 241-247 (1992)

18. Carroll, M. C. The role of complement in B cell activation and tolerance. Adv. Immunol. 74, 61-88 (2000).

19. Korb, L. C. \& Ahearn, J. M. C1q binds directly and specifically to surface blebs of human keratinocytes: complement deficiency and systemic lupus erythematosus revisited. J. Immunol. 158, 4525-4528 (1997).
20. Botto, M. et al. Homozygous C1q deficiency causes glomerulonephritis associated with multiple apoptotic bodies. Nat. Genet. 19, 56-59 (1998).

21. Gullstrand, B., Mårtensson, U., Sturfelt, G., Bengtsson, A. A. \& Truedsson, L. Complement classical pathway components are all important in clearance of apoptotic and secondary necrotic cells. Clin. Exp. Immunol. 156, 303-311 (2009).

22. Yamada, M. et al. Complement C1q regulates LPS-induced cytokine production in bone marrowderived dendritic cells. Eur. J. Immunol. 34, 221-230 (2004).

23. Lood, C. et al. C1q inhibits immune-complex induced interferon- $\alpha$ production in plasmacytoid dendritic cells. Arthritis Rheum. 60, 3081-3090 (2009).

24. Lövgren, T., Eloranta, M. L., Båve, G., Alm, G. V. \& Rönnblom, L. Induction of interferon- $\alpha$ production in plasmacytoid dendritic cells by immune complexes containing nucleic acid released by necrotic or late apoptotic cells and lupus IgG. Arthritis Rheum. 50, 1861-1872 (2004).

25. Molina, $\mathrm{H}$. Update on complement in the pathogenesis of systemic lupus erythematosus. Curr. Opin. Rheumatol. 14, 492-497 (2002).

26. Shlomchik, M. J. \& Madaio, M. P. The role of antibodies and B cells in the pathogenesis of lupus nephritis. Springer Semin. Immunopathol. 24, 363-375 (2003).

27. Mostoslavsky, G. et al. Lupus anti-DNA autoantibodies cross-react with a glomerular structural protein: a case for tissue injury by molecular mimicry. Eur. J. Immunol. 31, 1221-1227 (2001)

28. Kalaaji, M., Sturfelt, G., Mjelle, J. E., Nossent, H. \& Rekvig, O. P. Critical comparative analyses of anti- $\alpha$-actinin and glomerulus-bound antibodies in human and murine lupus nephritis. Arthritis Rheum. 54, 914-926 (2006).

29. Kalaaji, M. et al. Glomerular apoptotic nucleosomes are central target structures for nephritogenic antibodies in human SLE nephritis. Kidney Int. 71, 664-672 (2007).

30. Schwartz, M. M., Korbet, S. M. \& Lewis, E. J. The prognosis and pathogenesis of severe lupus glomerulonephritis. Nephrol. Dial. Transplant. 23 1298-1306 (2008)

31. Sturfelt, G. \& Sjöholm, A. G. Complement components, complement activation and acute phase response in systemic lupus erythematosus. Int. Arch. Allergy Appl. Immunol. 75, 75-83 (1984).

32. Najafi, C. C., Korbet, S. M., Schwartz, M. M., Reichlin, M. \& Evans, J. Significance of histologic patterns of glomerular injury upon long-term prognosis in severe lupus glomerulonephritis. Kidney Int. 59, 2156-5163 (2001).

33. Sjöholm, A. G., Mårtensson, U. \& Sturfelt, G. Serial analysis of autoantibody responses to the collagen-like region of Cla, collagen type II, and double stranded DNA in patients with systemic lupus erythematosus. J. Rheumatol. 24, 871-878 (1997).

34. Antes, U., Heinz, H. P. \& Loos, M. Evidence for the presence of autoantibodies to the collagenlike portion of $\mathrm{C} 1 \mathrm{q}$ in systemic lupus erythematosus. Arthritis Rheum. 31, 457-464 (1988).

35. Trouw, L. A. \& Daha, M. R. Role of anti-C1q antibodies in the pathogenesis of lupus nephritis. Expert Opin. Biol. Ther. 5, 243-251 (2005).

36. Bigler, C., Schaller, M., Perahud, I., Osthoff, M. \& Trendelenburg, M. Autoantibodies against complement $\mathrm{C} 1 \mathrm{q}$ specifically target $\mathrm{C} 1 \mathrm{q}$ bound on early apoptotic cells. J. Immunol. 183 3512-3521 (2009).
37. Trouw, L. A., Seelen, M. A. \& Daha, M. R. Complement and renal disease. Mol. Immunol. 40, 125-134 (2003)

38. Pickering, M. C. et al. Uncontrolled C3 activation causes membranoproliferative glomerulonephritis in mice deficient in complement factor $\mathrm{H}$. Nat. Genet. 31, 424-428 (2002).

39. Nielsen, C. T. et al. Increased IgG on cell-derived plasma microparticles in systemic lupus erythematosus is associated with autoantibodies and complement activation. Arthritis Rheum. 64, 1227-1236 (2012).

40. Yousefi, S., Mihalache, C., Kozlowski, E., Schmid, I. \& Simon, H. U. Viable neutrophils release mitochondrial DNA to form neutrophil extracellular traps. Cell Death Differ. 16, 1438-1444 (2009).

41. Hakkim, A. et al. Impairment of neutrophil trap degradation is associated with lupus nephritis. Proc. Natl Acad. Sci. USA 107, 9813-9818 (2010).

42. Hom, G. et al. Association of systemic lupus erythematosus with C8orf13-BLK and ITGAMITGAX. N. Engl. J. Med. 358, 900-909 (2008).

43. Lande, R. et al. Neutrophils activate plasmacytoid dendritic cells by releasing self-DNA-peptide complexes in systemic lupus erythematosus. Sci. Transl. Med. 3, 73 ra19 (2011).

44. Jacob, H. S., Craddock, P. R., Hammerschmidt, D. E. \& Moldow, C. F. Complement-induced granulocyte aggregation: an unsuspected mechanism of disease. N. Engl. J. Med. 302, 789-794 (1980)

45. Abrahamson, S. B., Given, W. P., Edelson, H. S. \& Weissmann, G. Neutrophil aggregation induced by sera from patients with active systemic lupus erythematosus. Arthritis Rheum. 26, 630-636 (1983).

46. Karpman, D. \& Kahn, R. The contact/kinin and complement systems in vasculitis. APMIS Suppl. 127, 48-54 (2009).

47. Ghiran, I. C. et al. Systemic lupus erythematosus serum deposits $\mathrm{C} 4 \mathrm{~d}$ on red blood cells, decreases red blood cell membrane deformability and promotes nitric oxide production. Arthritis Rheum. 63, 503-512 (2011)

48. Gewurz, H., Ying, S. C., Jiang, H. \& Lint, T. F. Nonimmune activation of the classical complement pathway. Behring Inst. Mitt. 93, 138-147 (1993)

49. Sjöwall, C. et al. Solid-phase classical complement activation by C-reactive protein (CRP) is inhibited by fluid-phase CRP-C1q interaction. Biochem. Biophys. Res. Commun. 352, 251-258 (2007).

50. Rodriguez, W. et al. Prevention and reversal of nephritis in MRL/Ipr mice with a single injection of C-reactive protein. Arthritis Rheum. 54, 325-335 (2006).

51. Carlucci, F., Cool, H. T., Garg, A., Pepys, M. B. \& Botto, M. Lack of effect of a single injection of human $\mathrm{C}$-reactive protein on murine lupus or nephrotoxic nephritis. Arthritis Rheum. 62 , 245-249 (2010)

52. Lim, W. Complement and the antiphospholipid syndrome. Curr. Opin. Hematol. 18, 361-365 (2011).

53. Holers, V. M. et al. Complement C3 activation is required for antiphospholipid antibody-induced fetal loss. J. Exp. Med. 21, 211-220 (2002).

54. Jönsson, G. et al. Rheumatological manifestations, organ damage and autoimmunity in hereditary $\mathrm{C} 2$ deficiency. Rheumatology (Oxford) 46, 1133-1139 (2007).

55. Welch, T. R., Frenzke, M., Witte, D. \& Davis, A. E. $3^{\text {rd }}$. C5a is important in the tubulointerstitial component of experimental immune complex glomerulonephritis. Clin. Exp. Immunol. 130, 43-48 (2002). 
56. Bao, L., Haas, M. \& Quigg, R. J. Complement factor $\mathrm{H}$ deficiency accelerates development of lupus nephritis. J. Am. Soc. Nephrol. 22, 285-295 (2011).

57. Jönsen, A. et al. Mutations in genes encoding complement inhibitors CD46 and CFH affect the age at nephritis onset in patients with systemic lupus erythematosus. Arthritis Res. Ther. 13, R206 (2011).

58. Burnham, T. K., Neblett, T. R. \& Fine, G. The application of the fluorescent antibody technic to the investigation of lupus erythematosus and various dermatoses. J. Invest. Dermatol. 41, 451-456 (1963).

59. Casciola-Rosen, L. \& Rosen, A. Ultraviolet lightinduced keratinocyte apoptosis: a potential mechanism for the induction of skin lesions and autoantibody production in LE. Lupus 6, 175-180 (1997).

60. Tveita, A. A., Ninomiya, Y., Sado, Y., Rekvig, O. P. \& Zykova, S. N. Development of lupus nephritis is associated with qualitative changes in the glomerular collagen IV matrix composition. Lupus 18, 355-360 (2009).

61. Petri, M., Watson, R., Winkelstein, J. A. \& McLean, R. H. Clinical expression of systemic lupus erythematosus in patients with $\mathrm{C} 4 \mathrm{~A}$ deficiency. Medicine (Baltimore) 72, 236-244 (1993).

62. Sturfelt, G., Sjöholm, A. G. \& Svensson, B. Complement components, $\mathrm{C} 1$ activation and disease activity in SLE. Int. Arch. Allergy Appl. Immunol. 70, 12-18 (1983).

63. Zadura, F. A., Theander, E., Blom, A. M. \& Trouw, L. A. Complement inhibitor C4b-binding protein in primary Sjögren's syndrome and its association with other disease markers. Scand. J. Immunol. 69, 374-380 (2009).

64. Ghererdi, R. K. Pathogenic aspects of dermatomyositis, polymyositis and overlap myositis. Presse Med. 40, 209-218 (2011).

65. Scambi, C. et al. Comparative proteomic analysis of serum from patients with systemic sclerosis and sclerodermatous GVHD. Evidence of defective function of factor H. PLOS ONE 5, e12162 (2010)

66. Trouw, L. A. et al. Genetic variants of $\mathrm{C} 1 \mathrm{q}$ are a risk for rheumatoid arthritis. Ann. Rheum. Dis. 70 (Suppl. 2), A17 (2011).

67. Hedberg, H. The depressed synovial complement activity in adult and juvenile rheumatoid arthritis. Acta Rheum. Scand. 10, 109-127 (1964).

68. Pekin, T. J. Jr \& Zvaifler, N. J. Hemolytic complement in synovial fluid Clin. Invest. 43, 1372-1382 (1964).

69. Hedberg, H., Lundh, B. \& Laurell, A. B. Studies on the third component of complement in synovial fluid from arthritic patients. II. Conversion and its relation to total complement. Clin. Exp. Immunol. 6, 707-712 (1970).

70. Sjöholm, A. G., Berglund, K., Johnson, U. Laurell, A. B. \& Sturfelt, G. C1 activation, with C19 in excess of functional $\mathrm{C} 1$ in synovial fluid from patients with rheumatoid arthritis. Int. Arch. Allergy Appl. Immunol. 79, 113-119 (1986).

71. Okroj, M., Heinegård, D., Holmdahl, R. \& Blom, A. M. Rheumatoid arthritis and the complement system. Ann. Med. 39, 517-530 (2007).

72. Nandakumar, K. S. et al. A recombinant vaccine effectively induces C5a-specific neutralizing antibodies and prevents arthritis. PLOS ONE 5, e13511 (2010)

73. Konttinen, Y. T. et al. Complement in acute and chronic arthritides: assessment of $\mathrm{C} 3 \mathrm{c}, \mathrm{C} 9$ and protectin (CD59) in synovial membrane. Ann. Rheum. Dis. 55, 888-894 (1996).
74. Jahn, B., von Kempis, J., Krämer, K. L. Filsinger, S. \& Hänsch, G. M. Interaction of the terminal complement components C5b-9 with synovial fibroblasts: binding to the membrane surface leads to increased levels in collagenasespecific mRNA. Immunology 78, 329-334 (1993).

75. Banda, N. K. et al. Role of C3a receptors, C5a receptors, and complement protein $\mathrm{C} 6$ deficiency in collagen antibody-induce arthrits in mice. J. Immunol. 188, 1469-1478 (2012).

76. Berckmans, R. J. et al. Cell-derived microparticles in synovial fluid from inflamed arthritic joints support coagulation exclusively via a factor XIIdependent mechanism. Arthritis Rheum. 46, 2857-2866 (2002).

77. Berglund, K., Laurell, A. B., Nived, O., Sjöholm, A. G. \& Sturfelt, G. Complement activation, circulating $\mathrm{C} 1 \mathrm{q}$ binding substances and inflammatory activity in rheumatoid arthritis: relations and changes on suppression of inflammation. J. Clin. Lab. Immunol. 4, 7-14 (1980).

78. Brodeur, J. P., Ruddy, S., Schwartz, L. B. \& Moxley, G. Synovial fluid levels of complement SC5b-9 and fragment $\mathrm{Bb}$ are elevated in patients with rheumatoid arthritis. Arthritis Rheum. 34, 1531-1537 (1991).

79. Hermansson, M. et al. MS analysis of rheumatoid arthritic synovial tissue identifies specific citrullination sites on fibrinogen. Proteomics Clin. Appl. 4, 511-518 (2010)

80. Trouw, L. A. et al. Anti-cyclic citrullinated peptide antibodies from rheumatoid arthritis patient activate complement via both the classical and the alternative pathways. Arthritis Rheum. 60 , 1923-1931 (2009).

81. Hanauske-Abel, H. M., Pontz, B. F. \& Schorlemmer, H. U. Cartilage specific collagen activates macrophages and the alternative pathway of complement: evidence of an immunopathogenetic concept of rheumatoid arthritis. Ann. Rheum. Dis. 41, 168-176 (1982).

82. Schaapherder, A. F., Gooszen, H. G., te Bulte, M. T. \& Daha, M. R. Human complement activation via the alternative pathway on porcine endothelium initiated by lgA antibodies. Transplantation 60, 287-291 (1995).

83. Kilpatrick, D. C. Mannan-binding lectin and its role in innate immunity. Transfus. Med. 12, 335-352 (2002).

84. Sjöberg, A., Önnerfjord, P., Mörgelin, M., Heinegård, D. \& Blom, A. M. The extracellular matrix and inflammation: fibromodulin activates the classical pathway of complement by directly binding C1q. J. Biol. Chem. 280, 32301-32308 (2005).

85. Happonen, K. E., Sjöberg, A. P., Mörgelin, M., Heinegård, D. \& Blom, A. M. Complement inhibitor C4b-binding protein interacts directly with small glycoproteins of the extracellular matrix. J. Immunol. 182, 1518-1525 (2009).

86. Groeneveld, T. W. et al. Interactions of the extracellular matrix proteoglycans decorin and biglycan with $\mathrm{C} 1 \mathrm{q}$ and collectins. J. Immunol. 175 , 4715-4723 (2005).

87. Happonen, K. E. et al. Regulation of complement by cartilage oligomeric matrix protein (COMP) allows for a novel molecular diagnostic principle in rheumatoid arthritis. Arthritis Rheum. 62 3574-3583 (2010).

88. Turesson, C. \& Matteson, E. L. Vasculitis in rheumatoid arthritis. Curr. Opin. Rheumatol. 21, 35-40 (2009).

89. Geirsson, A. J., Sturfelt, G. \& Truedsson, L. Clinical and serological features of severe vasculitis in rheumatoid arthritis: prognostic implications. Ann. Rheum. Dis. 46, 727-733 (1987).
90. Wang, Q. et al. Identification of a central role for complement in osteoarthritis. Nat. Med. 17, 1674-1679 (2011)

91. Xiao, H. et al. Alternative complement pathway in the pathogenesis of disease mediated by antineutrophil cytoplasmic autoantibodies. Am. J. Pathol. 170, 52-64 (2007).

92. Schreiber, A. et al. C5a receptor mediates neutrophil activation and ANCA-induced glomerulonephritis. J. Am. Soc. Nephrol. 20, 289-298 (2009).

93. Huugen, D. et al. Inhibition of complement factor C5 protects against anti-myeloperoxidase antibody-mediated glomerulonephritis in mice. Kidney Int. 71, 646-654 (2007).

94. Kose, A. A. Direct immunofluorescence in Behçet's disease: a controlled study with 108 cases. Yonsei Med. J. 50, 505-511 (2009).

95. Mårtensson, U., Sjöholm, A. G., Sturfelt, G. Truedsson, L. \& Laurell, A. B. Western blot analysis of human IgG reactive with the collagenous portion of C1q: evidence of distinct binding specificities. Scand. J. Immunol. 35, 735-744 (1992).

96. Mehregan, D. R. \& Gibson, L. E. Pathophysiology of urticarial vasculitis. Arch. Dermatol. 134 88-89 (1998).

97. Emlen, W., Li, W. \& Kirschfink, M. Therapeutic complement inhibition: new developments. Semin. Thromb. Hemost. 36, 660-668 (2010).

98. Longhurst, H. \& Cicardi, M. Hereditary angiooedema. Lancet 379, 474-481 (2012).

99. Garred, P. et al. Mannose-binding lectin (MBL) therapy in an MBL-deficient patient with severe cystic fibrosis lung disease. Pediatr. Pulmonol. 33, 201-207 (2002).

100. Mehta, P. et al. SLE with C1q deficiency treated with fresh frozen plasma: a 10-year experience. Rheumatology (Oxford) 49, 823-824 (2010).

101. Steinsson, K., Erlendsson, K. \& Valdimarsson, H. Successful plasma infusion treatment of a patient with $\mathrm{C} 2$ deficiency and systemic lupus erythematosus: clinical experience over forty-five months. Arthritis Rheum. 32, 906-913 (1989).

102. Weisman, H. F. et al. Soluble human complement receptor type 1: in vivo inhibitor of complement suppressing post-ischemic myocardial inflammation and necrosis. Science 249, 146-151 (1990).

103. Jennette, J. C., Xiao, H., Falk, R. \& Gasim, A. M. Experimental models of vasculitis and glomerulonephritis induced by antineutrophil cytoplasmic antibodies. Contrib. Nephrol. 169, 211-220 (2011).

104. Macor, P. et al. Treatment of arthritis models by targeting synovial endothelium with a neutralizing recombinant antibody to $\mathrm{C5}$. Arthritis Rheum. http://dx.doi.org/10.1002/art.34430.

105. Kolla, R. V. et al. Complement C3d conjugation to anthrax protective antigen promotes a rapid, sustained, and protective antibody response. PLOS ONE 2, e1044 (2007).

106. Wu, Y. L., Brookshire, B. P., Verani, R. R., Arnett, F. C. \& Yu, C. Y. Clinical presentations and molecular basis of complement $\mathrm{C} 1 \mathrm{r}$ deficiency in a male African-American patient with systemic lupus erythematosus. Lupus 20, 1126-1134 (2011).

107. Fijen, C. A. et al. Properdin deficiency: molecular basis and disease association. Mol. Immunol. 36, 863-867 (1999).

108. Witzel-Schlömp, K. et al. Heterogeneity in the genetic basis of human complement $\mathrm{C} 9$ deficiency. Immunogenetics 48, 144-147 (1998).

Author contributions

G. Sturfelt and L. Truedsson contributed equally to researching data for the article, discussions of the content, writing the article and review and/or editing of the manuscript before submission. 